University of Wollongong

Research Online

Faculty of Informatics - Papers (Archive)

Faculty of Engineering and Information

Sciences

$1-1-2006$

\title{
Benefits of ICT adoption and use in regional general medical practices: a pilot study
}

\author{
Robert Macgregor \\ University of Wollongong, rmacgreg@uow.edu.au \\ Peter Hyland \\ University of Wollongong, phyland@uow.edu.au \\ Charles Harvie \\ University of Wollongong, charvie@uow.edu.au \\ Boon-chye Lee \\ University of Wollongong, boon@uow.edu.au \\ Andrew Dalley \\ University of Wollongong, adalley@uow.edu.au
}

See next page for additional authors

Follow this and additional works at: https://ro.uow.edu.au/infopapers

Part of the Physical Sciences and Mathematics Commons

\section{Recommended Citation}

Macgregor, Robert; Hyland, Peter; Harvie, Charles; Lee, Boon-chye; Dalley, Andrew; and Ramu, Sangeetha: Benefits of ICT adoption and use in regional general medical practices: a pilot study 2006, 23-35. https://ro.uow.edu.au/infopapers/1325 


\title{
Benefits of ICT adoption and use in regional general medical practices: a pilot study
}

\author{
Abstract \\ This paper presents a pilot study of benefits derived from information and communications technology \\ (ICT) adoption and use in medical practices in regional Australia. The study involved 122 regional medical \\ practitioners. The results show that like the more general small businesssector, the perception of certain \\ benefits is associated with the size of the practice (in terms of employee levels) and/ or the gender of the \\ respondent practitioner.

\section{Keywords} \\ Benefits, ICT, adoption, use, regional, general, medical, practices, pilot, study

\section{Disciplines} \\ Physical Sciences and Mathematics

\section{Publication Details} \\ Macgregor, R. C., Hyland, P. N., Harvie, C., Lee, B. C., Dalley, A. \& Ramu, S. (2006). Benefits of ICT adoption \\ and use in regional general medical practices: a pilot study. Health Information Management Journal, 35 \\ (3), 23-35.
}

\section{Authors}

Robert Macgregor, Peter Hyland, Charles Harvie, Boon-chye Lee, Andrew Dalley, and Sangeetha Ramu 


\title{
Benefits of ICT adoption and use in regional general medical practices: a pilot study
}

Rob MacGregor, Peter Hyland, Charles Harvie, Boon-Chye Lee, Andrew Dalley and Sangeetha Ramu

\begin{abstract}
This paper presents a pilot study of benefits derived from information and communications technology (ICT) adoption and use in medical practices in regional Australia. The study involved 122 regional medical practitioners. The results show that like the more general small business sector, the perception of certain benefits is associated with the size of the practice (in terms of employee levels) and/or the gender of the respondent practitioner. The data also showed that the level of skill of certain software used within the practice was significantly associated with the level of perceived benefit derived from ICT adoption and use.
\end{abstract}

\section{Keywords (MeSH):}

Information Systems; Information Management; Technology; Communication; Utilisation; General Practice

\section{Introduction}

The use of information and communications technology (ICT) in medical practices is by no means a new phenomenon (see for example Ammenwerth et al. 2003; Waring \& Wainwright 2002; Shohet \& Lavy 2004; Catalan 2004). A recent study of Australian general medical practitioners (Henderson, Britt \& Miller 2006) showed that $89.9 \%$ of practices used a computer for billing and accounting, $85 \%$ of GPs indicated that they prescribed electronically, $73.8 \%$ ordered tests electronically, while only $29.5 \%$ of practices had fully automated their patient records. The study concluded that despite the physical presence of computers, many GPs were reluctant to fully embrace the technology.

While studies concerned with ICTs and GPs provide useful data on the use of these technologies in general practice, a closer examination shows that many have failed to examine their findings from the wider SME (small and medium sized enterprises) literature. Many of these 'wider' studies have shown that, amongst other things, business size, gender, and IT skills are associated with the perception of benefits derived from ICT use.

This study has a twofold purpose. Firstly, it examines the perception of benefits derived from ICT adoption. Secondly, the study aims to determine whether the size of the practice, the number of patients treated, the gender of the practitioner or the level of computing skills of the practitioner are associated with the perception of benefits.

The paper begins by examining the nature of benefits derivable from ICT adoption and use, both from a general SME perspective as well as from a medical perspective. The paper then examines the findings of SME studies, particularly the role of business size, gender and computer skills in the perception of benefits derived from ICT adoption and use. This is followed by a study of 65 medical practitioners from two regional locations in NSW, Australia.

\section{Benefits of ICT adoption (SMEs)}

There have been many studies concerned with the benefits derived from ICT adoption. Some of these studies (MacGregor 2004) have shown that benefits are often intangible; that is, they are 
often not realised by owner/managers at the time of adoption. The following section examines some of those findings.

Studies by Poon \& Swatman (1997) and Abell \& Lim (1996) found that SMEs benefited in their ability to reach new customers and new markets through the use of ICT. This finding has been supported in more recent studies (Vescovi 2000; Ritchie \& Brindley 2000; Sparkes \& Thomas 2001; Raymond 2001; Quayle 2002).

Earlier studies found that other benefits reported by SME operators included:

- lowering of administration costs (Poon \& Swatman 1997; Abell \& Lim 1996),

- reduced lead time (Abell \& Lim 1996),

- increased sales (Abell \& Lim 1996),

- improved relations with business partners (Poon \& Swatman 1997)

- improved quality of information (Poon \& Swatman 1997; Abell \& Lim 1996).

A recent study by Quayle (2002) found that benefits derived from ICT use, as reported by SME owner/managers, included reduced administration costs, reduced production costs, reduced lead time, reduced stock, improved marketing and improved quality of information, while Tetteh and Burn (2001) found the adoption of ICTs substantially increased internal efficiency.

As noted previously, many of the benefits enjoyed by small businesses are intangible. Woerndl, Powell and Vidgen (2005) found that many small businesses involved in ICT use had expanded their activities beyond those performed prior to its adoption. Stockdale and Standing (2004) found that benefits included changes in business methods and costs, enhanced levels of communication, stimulated competition and reduced transaction costs. Hurwitz Group (2000) concluded that ICT adoption led to greater potential for partnerships, while Brunn, Jensen and Skovgaard (2002) showed that ICT use led to flexibility in administration and communication.

\section{Benefits of ICT adoption (medical practices)}

As noted above, the adoption and use of ICT within the healthcare sector is not entirely a new phenomenon. Studies of the National Health Service (NHS) in the UK by Gallagher (1998) noted that benefits included the ability to undertake strategic planning and better manage the healthcare environment. Rees (1998), in a similar study, noted that the use of ICT appeared to enhance efficiency. Pullen, Atkinson and Tucker (2000) showed that costs were better managed using certain forms of ICTs. These studies are supported by the findings of Nelson and Alexander (2002). It is interesting to note, however, that despite the apparent benefits, the approach to the design of ICT inclusions has been questioned by several authors who noted that many fail to fully account for all the stakeholders of the enhanced system (Waring \& Wainwright 2002; Shohet \& Lavy 2004; Gelnay 2002).

Other benefits noted in the literature include:

- contacting other clinicians regarding patient care (Qavi, Corley \& Kay 2001; Baldwin, Clarke \& Jones 2002)

- elimination of redundancy in patient care (Pelletier-Fleury et al. 1999)

- enhancements to the effectiveness of the practice (Andersson, Vimarlund \& Timpka 2002)

- control of economic demands (Prop 2000)

- improved patient care (Leung et al. 2003)

- order entry of consumables by the practice (Ash et al. 2004).

\section{The impact of business size on the adoption and use of ICTs}

Many studies have examined the impact of business characteristics in the adoption and use of ICTs. Several studies (Fallon \& Moran 2000; Matlay 2000; Matlay \& Fletcher 2000; Culkin \& Smith 2000; Riquelme 2002) have found that the adoption of IT is significantly associated with business size (in terms of either the number of employees or turnover) . Culkin and Smith (2000) suggest that larger SMEs are by nature inherently more complex and thus decisions concerning IT acquisition require more detailed examinations of the impact of IT. Larger SMEs tend to adopt more sophisticated systems and very often are more likely to 'computerise' far more of their business than smaller SMEs. Similarly, studies by Blackburn and Athayde (2000) and MacGregor and Vrazalic (2006) found significant links between the level of Internet adoption and the business size (defined in terms of the number of employees). 


\section{The impact of computer skills on the adoption and use of ICTs}

The level of computer skill also appears to have an impact on the adoption and use of ICTs. Studies in Singapore (Yap, Soh \& Raman 1992; Thong, Yap \& Raman 1996) and Australia (MacGregor \& Bunker 1996; MacGregor, Bunker \& Waugh 1998) have shown that the level of IT skill within an SME is a strong determinant of the type of IT acquired as well as the ongoing success of that IT. More recently, studies in Australia and the UK (Tetteh \& Burn 2001; O'Donnell et al. 2001) have concluded that successful ICT adoption is associated with the level of IT skill within the SME.

\section{The impact of gender on the adoption and use of ICTs}

Early studies (Gilroy \& Desai 1986; Meier \& Lambert 1991) found that males were less anxious about using computer technology than females. In later suties, both Shade (1998) and Sheehan (1999) found that females were more concerned with privacy and security issues and subsequently more cautious about using the Internet. Where the adoption and use of ICT is concerned, a study of 112 SMEs in Spain (Perez, Carnicer \& Sanchez 2002) found that small businesses with female managers were significantly more concerned with the difficulty of using the technology than were their male counterparts. The study also cited the cost of the technology and changes to work procedures as being of more concern to female managers. In a recent study of 350 Swedish SMEs, MacGregor and Vrazalic (2006) found that ratings by male respondents of all 11 possible benefits were significantly higher than those of their female counterparts.

\section{Methods}

Following an analysis of both general SME studies as well as previous medical studies, 17 benefits of ICT adoption and use in general practice were identified. A series of interviews were conducted with representatives of the Illawarra Division of General Practice to determine the appropriateness of the benefits to the GP community. All benefits were considered relevant and no others were forthcoming. These interviews also explored the notions of business size and expertise in the use of IT. The notion of business size was considered to be both a function of the number of staff as well as the number of patients treated per week. Five categories were nominated for the numbers of staff, while six categories were nominated for the numbers of patients treated (see Appendix A). Seven different IT uses were determined. A 5-point Likert scale was used to examine the importance/non-importance of the 17 benefits (see Appendix A for details of the interview questions).

A questionnaire was then developed (see Appendix B). Respondents were asked the size of the practice both in terms of staff and in terms of the average patient numbers per week, to rate their level of skill in each of the seven IT uses and to rate the 17 benefits across the 5-point Likert scale.

Six hundred and ninety questionnaires were distributed by mail to all GPS in the Illawarra, Hunter, Rockhampton, Ballarat and SE NSW Divisions of General Practice.

\section{Results}

Responses were obtained from $122 \mathrm{GPs}$, giving a $17.7 \%$ response rate. Table 1 provides the profile of respondents.

While the response rate was lower than expected it still fell within acceptable statistical boundaries so that further analysis could proceed.

An examination of Table 1 shows that 56.6\% of the respondent practices were either one- or two-doctor practices. This is higher than the national average, but is close to the average for non-metropolitan general practices. Seventy point five percent of respondents indicated that they saw more than 90 patients per week, with $27.9 \%$ seeing more than 150 patients per week.

There were $27.9 \%$ female GPs among the respondents. This is higher than the Australian government figures of $23.5 \%$ (Australian Government Department of Health \& Ageing 2006).

With the exception of IT skills specifically aimed at generating invoices, over two-thirds of the respondents indicated that they had an average or higher level of IT skills with all the software types tested. This suggests that the 
Table 1: Profile of respondents

\begin{tabular}{lc}
$1-2$ person practice & 18 \\
\hline $3-5$ person practice & 50 \\
\hline $6-10$ person practice & 29 \\
\hline $11-20$ person practice & 18 \\
\hline$>20$ person practice & 5 \\
\hline & Missing 2 \\
\hline
\end{tabular}

$<30$ patients per week

30-60 patients per week

61-90 patients per week

91-120 patients per week

121-150 patients per week

$>150$ patients per week

Female respondent

\begin{tabular}{|c|c|c|c|c|c|c|}
\hline SKILL & & VERY POOR & POOR & AVERAGE & GOOD & VERY GOOD \\
\hline Word Processing & 4 missing & 5 & 13 & 46 & 41 & 13 \\
\hline Spreadsheet & 3 missing & 29 & 35 & 21 & 28 & 6 \\
\hline Data Entry & 3 missing & 12 & 25 & 35 & 33 & 14 \\
\hline Generating Invoices & 6 missing & 31 & 34 & 21 & 18 & 12 \\
\hline Internet Email & 2 missing & 2 & 8 & 21 & 58 & 31 \\
\hline Internet Information Retrieval & 2 missing & 2 & 6 & 24 & 53 & 35 \\
\hline Medical Software & 4 missing & 5 & 5 & 20 & 49 & 39 \\
\hline
\end{tabular}

responses obtained from the survey were from well-informed respondents who were familiar with the use of computer technology.

Both the ratings of benefits and the rating of ICT skills were tested for internal consistency. The Cronbach's Alpha for the benefits was .942, while for the ratings of ICT skills, it was 0.884 .

A weighted average technique was applied to the benefits in order to determine the overall ranking of importance (see Table 2).

Table 2. Frequency and ranking of benefits of ICT adoption and use

\begin{tabular}{|c|c|c|c|c|c|c|}
\hline BENEFIT & $\begin{array}{l}\text { VERY } \\
\text { NIMPORTANT }\end{array}$ & UNIMPORTANT & $\begin{array}{c}\text { NEITHER } \\
\text { IMPORTANT NO } \\
\text { UNIMPORTANT }\end{array}$ & IMPORTANT & $\begin{array}{c}\text { YERY } \\
\text { IMPORTANT }\end{array}$ & RANK \\
\hline Information storage and retrieval & 5 & 2 & 15 & 40 & 55 & 1 \\
\hline Streamlining accounting and billing & 7 & 4 & 10 & 48 & 50 & 2 \\
\hline Disease management & 13 & 6 & 20 & 56 & 24 & 3 \\
\hline Improvement in the way the business is operated & d 10 & 6 & 17 & 68 & 16 & 4 \\
\hline Adding to the skills of the practice & 11 & 7 & 33 & 45 & 24 & 5 \\
\hline Improvement to business efficiency & 13 & 14 & 18 & 52 & 22 & 6 \\
\hline Communication with other medical organisations & is 14 & 12 & 38 & 42 & 14 & 7 \\
\hline Communication with fellow GPs & 18 & 16 & 29 & 41 & 16 & 8 \\
\hline Communication with hospitals & 19 & 15 & 30 & 42 & 11 & 9 \\
\hline More time on patient care & 23 & 11 & 40 & 31 & 14 & 10 \\
\hline Allowing the business to expand & 22 & 19 & 32 & 35 & 12 & 11 \\
\hline Reduction of costs & 20 & 14 & 30 & 35 & 7 & 12 \\
\hline $\begin{array}{l}\text { Reducing the importance of remoteness } \\
\text { in the provision of medical care }\end{array}$ & 27 & 17 & 32 & 29 & 12 & 13 \\
\hline Ordering drugs & 27 & 19 & 36 & 25 & 11 & 14 \\
\hline Reduction of the overall workload & 27 & 15 & 37 & 29 & 6 & 15 \\
\hline $\begin{array}{l}\text { Communication with general practice } \\
\text { business suppliers }\end{array}$ & 31 & 23 & 38 & 21 & 5 & 16 \\
\hline $\begin{array}{l}\text { Expanding the patient/customer base } \\
\text { by broadening the area of coverage }\end{array}$ & 41 & 21 & 36 & 19 & 2 & 17 \\
\hline
\end{tabular}


An examination of Table 2 shows that eight of the 17 benefits had a mean frequency rating of three or above. This would suggest that, for the Australian regional general practitioners, the benefits derived from adoption and use of ICT were lower than in previous studies, be they general SMEs or medical practices. Only two benefits had an average rating in the very important range. These were information retrieval and storage and streamlining billing and accounting functions. While these may be achievable through ICT use, they are equally achievable through non-ICT methods. It is interesting to note that only one of the top five ranked benefits is medical.

Of particular interest were the lower ranking benefits. Unlike much of the literature, concerning both general SME use of ICTs and medical use of ICTs, the adoption and use of ICT in regional Australian medical practices appeared not to have reduced costs or workloads, nor had it had any apparent benefit in terms of communication with suppliers, reduction of concerns regarding remoteness nor expanding the patient base of the practice.

A series of linear regressions was applied to each of the benefits to determine whether any of the factors (business size, gender, IT skills) was associated with the ratings of the benefits. Linear regressions were used to compensate for the possibility that some of the factors (business size, gender, IT skills) may, themselves, be mutually dependent.

For brevity, only those regressions that showed a statistically significance are shown.

Table 3: Regression table for improvement to business efficiency

DEPENDANT VARIABLE: Improvement to business efficiency BETA

PVALUE

Use of medical packages

.226 .047

\begin{tabular}{ll}
$R$ squared & .233 \\
\hline Adjusted $R$ squared & .163 \\
\hline$p$ value for the complete regression table & .001 \\
\hline
\end{tabular}

An examination of Table 3 shows that there is a significant association between the level of ability with the use of medical packages and the perception that ICTs improve business efficiency.
The positive Beta value shows that the higher the level of ability with medical packages, the greater the perception that ICTs do benefit the practice in terms of improvement to business efficiency. As the use of ICTs would normally include medical packages, this result would be expected. It is interesting to note that business size is not associated with improvement to business efficiency, as might have been expected. A number of studies, albeit in the general SME literature (see Fallon \& Moran 2000; Blackburn \& Athayde 2000) have suggested that one of the benefits of ICT adoption, particularly for larger SMEs is improvement to internal efficiency. The current study does not support those previous findings.

Table 4: Regression table for enabling more time to spend on patient care

DEPENDANTVARIABLE: Enabling more time to spend on patient care

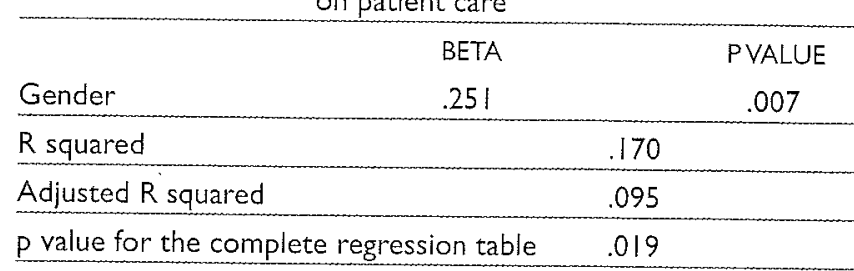

Table 4 provides an interesting result. The only factor associated with the benefit enabling more time to spend on patient care was gender. The positive Beta value suggests that female GPs place a higher level of importance on this benefit as an outcome of ICT adoption and use, than do male GPs. In one respect, the results support earlier findings (Boerma \& van den Brink-Muinen 2000, van den Brink-Muinen, Bensing \& Kerssens 1998) that showed that female GPs normally allocated more time to patients than male GPs. However, these same studies also showed that female GPs were less technically minded and used far less technology than their male counterparts. 
Table 5: Regression table for improvement in the way the business is operated

DEPENDANT VARIABLE: Improvement in the way the business is operated

\begin{tabular}{lcc}
\hline & BETA & PVALUE \\
Use of medical packages & .289 & .013 \\
\hline$R$ squared & & .139 \\
\hline Adjusted $R$ squared & .003 & \\
\hline$P$ value for the complete regression table & & \\
\hline
\end{tabular}

Table 5 provides a very similar finding to that shown in Table 3. As might be expected, those who had a higher perceived level of ability with medical packages saw higher benefits derived from ICT adoption by way of improving the way the business was operated. Conventional wisdom might have suggested that ICT adoption would have benefited larger practices more than smaller ones. Again, the data showed no association between business (either in terms of personnel or patient numbers) and the benefit improvement to the way the business is operated.

Table 6: Regression table for allowing the business to expand

DEPENDANTVARIABLE: Allowing the business to expand

\begin{tabular}{lcc} 
Gender & $\begin{array}{c}\text { BETA } \\
256\end{array}$ & $\begin{array}{c}\text { PVALUE } \\
.003\end{array}$ \\
\hline R squared & .238 & \\
\hline Adjusted $R$ squared & .169 & \\
\hline$p$ value for the complete regression table & .001 & \\
\hline
\end{tabular}

Table 6 provides an interesting and unexpected outcome. While expansion of the business was rated the lowest of all of the benefits (see Table 2), the data in Table 6 shows a highly significant association between the gender of the respondent GP and the perception of importance of that benefit. Again, the positive Beta value shows that female GPS see this benefit as being more important than do male GPs. The level of significance $(p=.003)$ shows that while females see some merit in this benefit, the males saw absolutely none at all.
Table 7: Regression table for information retrieval and storage

DEPENDANT VARIABLE: Information retrieval and storage

\begin{tabular}{|c|c|c|c|}
\hline & BETA & & PVALUE \\
\hline Use of medical packages & .327 & & .005 \\
\hline $\mathrm{R}$ squared & \multicolumn{3}{|c|}{.235} \\
\hline Adjusted R squared & \multicolumn{3}{|c|}{.165} \\
\hline $\mathrm{P}$ value for the complete & \multicolumn{3}{|c|}{.001} \\
\hline
\end{tabular}

The results in Table 7 are again similar to the results in Tables 3 and 5. As might be expected, those respondents who had a higher level of skill in the use of medical packages, also found greater benefits in terms of information retrieval and storage. Again, previous studies in the wider SME sector have shown that this benefit is significantly associated with business size; the larger the business, the more importance is placed on the benefit by respondents. No such association was found in the current study.

Table 8: Regression table for communication with fellow GPs

DEPENDANTVARIABLE: Communication with fellow GPS

\begin{tabular}{lcc}
\hline & BETA & PVALUE \\
Practice size staff & .192 & .035 \\
\hline Gender & .218 & .015 \\
\hline R squared & & \\
\hline Adjusted R squared & .197 \\
\hline p value for the complete regression table & .005 \\
\hline
\end{tabular}

While the association between communications with fellow GPs and the size of the practice (in terms of personnel) was expected, the association with gender was unexpected. Again, the positive Beta value shows that female GPs rated the importance of this benefit higher than the males. This result is contrary to earlier findings (see Boerma \& van den Brink-Muinen 2000; van den Brink-Muinen, Bensing \& Kerssens 1998). 
Iadie y: Kegression table for communication with other medical organisations

DEPENDANTVARIABLE: Communication with other medical organisations

\begin{tabular}{lccc}
\hline & BETA & PVALUE \\
Practice size staff & .193 & .036 \\
\hline Use of medical packages & .254 & & .031 \\
\hline R squared & .179 & \\
\hline Adjusted R squared & .105 & \\
\hline P value for the complete regression table & .102 & \\
\hline
\end{tabular}

The results in Table 9 are similar to those found in Tables 3, 5 and 7. As would be expected, those who had a higher level of skill with the use of medical packages saw a greater benefit from communication with other medical organisations. However, unlike the earlier findings, the positive Beta results show that it is the larger practices (in terms of personnel) that saw a greater benefit compared to the smaller ones.

Table 10: Regression table for adding to the skills of the practice

DEPENDANT VARIABLE: Adding to the skills of the practice

\begin{tabular}{|c|c|c|}
\hline & BETA & PVALUE \\
\hline Practice size staff & .212 & .011 \\
\hline Gender & .183 & .024 \\
\hline Use of medical packages & .331 & .002 \\
\hline R squared & \multicolumn{2}{|c|}{.332} \\
\hline Adjusted R squared & \multicolumn{2}{|c|}{.272} \\
\hline$p$ value for the complete & \multicolumn{2}{|c|}{.000} \\
\hline
\end{tabular}

Table 10 shows the associations with the benefit 'adding to the skills of the practice'. Although two of the associations in Table 10 (practice size and level of skill with medical packages) were expected, the third association, with gender, was unexpected. Again, the positive Beta value shows that female GPs rated this benefit as being more important than the males. A number of studies (Sandberg 2003, Verheul, Risseeuw \& Bartelse 2002) have noted that females tend to be more conscious of their staff than males, however, similar studies (Boerma \& van den Brink-Muinen 2000; van den BrinkMuinen, Bensing \& Kerssens 1998) found that females tended to be more anxious with technology.

\section{Discussion}

This study has shown that while the adoption rate of ICTs within regional general practices is high, GPs have not been able to derive the same benefits from ICT adoption that other SMEs have done. Indeed, only 6 of the 17 benefits had a mean greater than three on a 5 -point Likert scale. Typically, this would be explained by claiming that general practices are intrinsically different to other SMEs, because GPs are professionals providing a medical service. However, the current study shows that the benefits that have been gained by GPs who are successful ICT adopters are not in the medical sphere but in the business sphere, Of the six benefits that were highly rated, only disease management was a clinical benefit; all the others are business benefits. When adopting ICT, GPs need to be more aware of the potential business benefits or they are unlikely to achieve them.

There may be a perception among GPs that ICT only provides benefits for practices with large numbers of patients, and hence a greater need for computerised medical records and the like. The current study shows that this is not the case. Practices with small numbers of patients can still gain from ICT use. Similarly, some GPs may think that ICT adoption is better suited to large practices where a larger staff needs ICT to communicate and streamline business activities. Once again, the current study shows that this is not true; ICT can benefit practices of all sizes.

A recent UK study (Keddie \& Jones 2005) concluded that much of the literature on ICT use in medical practices was little more than an assessment of the software, without due consideration to training medical users as to the best implementation strategies. While not explicitly examined in the present study, our results support this observation and we would suggest that GPs should focus on the adoption strategies that are to be found in the SME literature, rather than focussing on specifically medical issues.

The results of the study have clearly shown that skill with medical packages has a positive impact on the perception of some benefits derived from ICT adoption. GPs who lack these skills may either be slow to adopt ICT or may not perceive the benefits of ICT adoption because they do not 
understand its technological possibilities. Our results suggest that developing such ICT skills among GPs may lead to a greater understanding of the potential benefits and hence improved business practices. While this study found the strongest association between perceived benefits and skill in the use of medical packages, our previous studies suggest that increased skill in any area of ICT use may increase the perception of benefits of ICT adoption in the practice. GPS would therefore gain a greater understanding of the benefits of ICT use by developing whatever ICT skills they can, but particularly skills with medical packages.

Of particular interest are the findings that female GPs gained greater benefit from ICT adoption and use than male GPs for certain benefits, including 'adding to the skills of staff', 'more time on patient care', 'allowing the business to expand' and 'communication with fellow GPs'. It is difficult to believe that male GPs would not see these benefits as being intrinsically of value, and yet male GPs do not see that ICT has produced these benefits in their practices. Knowing that these benefits are being achieved by female GPs may cause them to adopt the strategies used by female GPs in their adoption of ICT, and hence gain these benefits as well. Alternatively, knowing that these benefits are achievable may lead male GPs to reassess whether ICT adoption has in fact provided these benefits in their practices without their noticing.

\section{Conclusion}

ICTs have the potential to capture and collate clinical data on patients, enabling a faster, more reliable and wide-ranging healthcare service, particularly for those patients in regional areas. Whilst this is a small study, the results suggest that, in regional Australia, the major benefits as seen by GPs are business oriented rather than clinically oriented. This raises concerns as to whether the adoption and use of ICTs within general practice in regional Australia has been undertaken with adequate consideration of strategies for ongoing use.

The results also suggest that the maximising of some benefits may be dependent on particular skills being 'in place', or that maximum benefits may only be achievable by specific practice sizes.
The results also point to differences existing between GPs themselves. While the current study has only examined gender differences, the increasing impact of computer use on medical services warrants further studies to be undertaken such that benefits derivable from ICT adoption and use can be maximised both for patients as well as the practitioners.

\section{References}

Abell, W. and Lim L. (1996). Business use of the Internet in New Zealand: an exploratory study. Available at: <http://ausweb.scu.edu.au/aw96/business/abell/paper. htm $>$ (accessed June 2006).

Ammenwerth, E., Mansmann, U., Iller, C. and Eichstadter, R. (2003). Factors affecting and affected by user acceptance of computer-based nursing documentation: results of a two-year study. Journal of the American Medical Informatics Association 10(1): 69-84.

Andersson A., Vimarlund V. \& Timpka T. (2002).

Management demands on information and communication technology in process-oriented healthcare organizations. Journal of Management in Medicine 16(23): 159-169.

Ash, S., Gorman, RN., Seshadri, V. and Hersh W.R. (2004). Perspectives on CPOE and patient care. Journal of the American Medical Informatics Association 11(2): 95-99.

Australian Government Department of Health and Ageing (n.d.). Available at: <http://www.health.gov.au/> (accessed June 2006).

Baldwin, L.P., Clarke, M. and Jones, R. (2002). Clinical ICT systems: augmenting case management. Journal of Management in Medicine16(2/3):188-198.

Blackburn, R. and Athayde, R. (2000). Making the connection: the effectiveness of Internet training in small businesses. Education and Training 42(4/5): 289-298.

Boerma, W.G.W. and van den Brink-Muinen. (2000). Genderrelated differences in the organisation and provision of services among general practitioners in Europe: a signal to health care planners. Medical Care 38(10): 993-1002.

Brunn, P., Jensen, M. and Skovgaard, J. (2002). eMarketplaces: crafting a winning strategy. European Management Journal 20(3): 286-298.

Catalan, J. (2004), internet medicine sales and the need for homogeneous regulation. International Journal of Medical Marketing 4(4): 342-349.

Culkin, N. and Smith, D. (2000), An emotional business: a guide to understanding the motivations of small business decision takers. Qualitative Market Research: An International Journal 3(3):145-157.

Fallon, M. and Moran, P. (2000). Information Communications Technology (ICT) and manufacturing SMEs. 2000 Small Business and Enterprise Development Conference, University of Manchester: 100-109.

Gallagher, M. (1998), Evolution of facilities management in the healthcare sector Construction paper no. 86, The Chartered Institute of Builders, Ascot: 1-8 
Gelnay, B. (2002). Facility management and the design of Victorian public hospitals Proceedings of the CIB Working Commission 70: Facilities Management and Maintenance Global Symposium 2002, Glasgow: 525-545.

Gilroy, F. and Desai, H. (1986). Computer anxiety: sex, race and age. International Joumal of Man-Machine Studies 25: 711-719.

Henderson, J., Britt, H. and Miller, G. (2006) Extent and utilisation of computerisation in Australian general practice. Medical Journal of Australia 185(2): 84-87.

Hurwitz Group (2000). e-Marketplaces: issues, risks and requirements for success. White Paper. Framingham, MA, Hurwitz Group Inc.

Keddie, Z. and Jones, R. (2005), Information communications technology in general practice: a cross sectional survey in London. Informatics in Primary Care 13(2): 113-124.

Leung, G.M., Yu, PL.H., Wong, I,O.L., Johnston, J.M. and Tin K.Y.K. (2003). Incentives and barriers that influence clinical computerisation in Hong Kong: a population based physician survey. Journal of the American Medical Informatics Association 10(2): 201-212.

MacGregor, R.C. (2004). The role of formal networks in the ongoing use of electronic commerce technology in regional small business. Journal of Electronic Commerce in Organisations 2(1): 1-14.

MacGregor, R.C. and Bunker, D.J. (1996). The effect of priorities introduced during computer acquisition on continuing success with it in small business environments. Information Resource Management Association International Conference, Washington: 271277.

MacGregor, R.C. and Vrazalic, L. (2006). e-Commerce adoption in regional SMEs. Hershey PA, Idea Group. (Forthcoming).

MacGregor, R.C., Bunker, D.J. and Waugh, P. (1998). Electronic commerce and small/medium enterprises (SMEs) in Australia: an electronic data interchange (EDI) pilot study. Proceedings of the 11th International Bled Electronic Commerce_Conference, Slovenia, June.

Matlay, H. (2000), Training in the small business sector of the British economy. In: Enterprise and small business: principles, policy and practice. S. Carter and D. Jones (Eds). London, Addison Wesley Longman: 323-336.

Matlay, H. and Fletcher, D. (2000). Globalisation and strategic change: some lesson from the UK small business sector. Strategic Change 9(7): 437-449.

Meier, S.T. and Lambert, M.E. (1991). Psychometric properties and correlates of three computer aversion scales. Behaviour Research Methods, Instruments and Computers 23(1): 9-15.

Nelson, M.L. and Alexander, K. (2002), The emergence of supply chain management as a strategic facilities management tool. In: K. Alexander (Ed.). Proceedings of the Euro FM Research Symposium in Facilities Management. The University of Salford.
O'Donnell, A., Gilmore, A., Cummins, D. and Carson, D (2001). The network construct in entrepreneurship research: a review and critique. Management Decision 39(9): 749-760.

Pelletier-Fleury, N., Lanoe, J.L., Philippe, C., Gagnadoux, F, Rakotonanahary, D. and Fleury, B. (1999). Economic studies and technical evaluation of telemedicine: the case of telemonitored polysomnography. Health Policy 49: 179-194

Perez, M.P, Carnicer, M.P.L. and Sanchez, A.M. (2002). Differential effects of gender perceptions of teleworking by human resources managers. Women in Management Review 17(6): 262-275.

Poon, S. and Swatman, P. (1997). The Internet for small businesses: an enabling infrastructure. Fifth Internet Society Conference: 221-231.

Prop (2000). Nationell handlingsplan for Utvekling av Halso-Och Sjukvarden No. 49. Sweden, Regeringen Och Regeringskansliet.

Pullen, S., Atkinson, D. and Tucker, S. (2000), Improvements in benchmarking the asset management of medical facilities. Proceedings of the International Symposium on Facilities Management and Maintenance, Brisbane: 265 271.

Qavi, T., Corley, L. and Kay, S. (2001). Nursing staff requirements for telemedicine in the neonatal intensive care unit. Journal of End User Computing 13(3): 5-13.

Quayle, M. (2002). E-commerce: the challenge for UK SMEs in the twenty-first century. International Journal of Operations and Production Management 2210: 1148 . 1161.

Raymond, L. (2001), Determinants of web site implementation in small business. Internet Research: Electronic Network Applications and Policy 11(5): 411 422.

Rees, D. (1998), Management structures of facility management in the national health service in England: a review of trends 1995-1997. Facilities 15(3/4): 254-261.

Riquelme, H. (2002). Commercial Internet adoption in China: comparing the experience of small, medium and large business. Internet Research: Electronic Networking Applications and Policy 12(3): 276-286.

Ritchie, R. and Brindley, C. (2000). Disintermediation, disintegration and risk in the SME global supply chain. Management Decision 38(8): 575-583.

Sandberg, K.W. (2003). An exploratory study of women in micro enterprises: gender related difficulties. Journal of Small Business and Enterprise Development 10(4): 408417.

Shade, L.R. (1998). A gendered perspective on access to the information infrastructure. The Information Society 14 : $33-44$.

Sheehan, K. (1999). An investigation of gender differences in on-line privacy concerns and resultant behaviour. Journal of Interactive Marketing 13(4): 24-38

Shohet, I.M. and Lavy, S. (2004). Healthcare facilities management: state of the art review. Facilities $22(7 / 8)$ : 210-220. 
Sparkes, A. and Thomas, B. (2001). The use of the Internet as a critical success factor for the marketing of Welsh agri-food SMEs in the twenty-first century. British Food Journal 103(4): 331-347.

Stockdale, R. and Standing, C. (2004). Benefits and

* barriers of electronic marketplace participation: an SME perspective. Information management 17(4): 301-309.

Tetteh, E. and Burn, J. (2001). Global strategies for SMEbusiness: applying the SMALL framework. Logistics Information Management 14: 171-180.

Thong, J.Y.L, Yap, C.S. and Raman, K.S. (1996). Top management support, external expertise and information systems implementation in small business. Information Systems Research 7(2): 248-267.

van den Brink-Muinen, A, Bensing, J.M. and Kerssens, J.J. (1998). Gender and communication style in general practice: differences between women's health care and regular health care. Medical Care 36: 100-106.

Verheul, I., Risseeuw, P. and Bartelse, G. (2002). Gender differences in strategy and human resource management. International Small Business Journal 20(4): 443-476.

Vescovi, T. (2000). Internet communication: the Italian SME case. Corporate Communications: An International Journal 5(2): 107-112.

Waring, T. and Wainwright, D. (2002). Enhancing clinical and management discourse in ICT implementation. Journal of management in Medicine 16(2/3): 133-149.

Woerndl, M., Powell, P. and Vidgen, R. (2005). Netsourcing in SMEs: e-ticketing in art venues. Electronic markets 15(2): 119

Yap, C.S., Soh, C.P.P and Raman, K.S. (1992). Information system success factors in small business. International Journal of management Science 20: 597-609.

\section{Rob MacGregor PhD}

\section{Associate Professor}

School of Information Technology and Computer Science

University of Wollongong

Wollongong NSW 2522

AUSTRALIA

Phone: +61242213758

Email:macgreg@uowedu.au

\section{Peter Hyland PhD}

Assistant Head

School of Information Technology and Computer Science

University of Wollongong

Wollongong NSW 2522

AUSTRALIA

\section{Charles Harvie PhD}

Co-director

Centre for Small Business and Regional Research

Faculty of Commerce

University of Wollongong

Wollongong NSW 2522

AUSTRALIA

\section{Boon-Chye Lee PhD, MBA}

Senior Lecturer

School of Economics and Information Systems, and

Co-Director

Centre for Small Business and Regional Research

University of Wollongong

Wollongong NSW 2522

AUSTRALIA

Andrew Dalley MBBS, DRACOG

Chief Executive Officer

Illawarra Division of General Practice

PO Box 1198

Illawarra NSW 2500

AUSTRALIA

\section{Sangeetha Ramu}

School of Information Technology and Computer Science

University of Wollongong

Wollongong NSW 2522

AUSTRALIA 